Louisiana State University

LSU Digital Commons

$1-1-2003$

\title{
Snow-patch influence on soil biogeochemical processes and invertebrate distribution in the McMurdo Dry Valleys, Antarctica
}

\author{
Michael N. Gooseff \\ University of Colorado Boulder \\ J. E. Barrett \\ Dartmouth College \\ Peter T. Doran \\ University of Illinois at Chicago \\ Andrew G. Fountain \\ Portland State University \\ W. Berry Lyons \\ Byrd Polar and Climate Research Center
}

See next page for additional authors

Follow this and additional works at: https://digitalcommons.Isu.edu/geo_pubs

\section{Recommended Citation}

Gooseff, M., Barrett, J., Doran, P., Fountain, A., Lyons, W., Parsons, A., Porazinska, D., Virginia, R., \& Wall, D. (2003). Snow-patch influence on soil biogeochemical processes and invertebrate distribution in the McMurdo Dry Valleys, Antarctica. Arctic, Antarctic, and Alpine Research, 35 (1), 91-99. https://doi.org/ 10.1657/1523-0430(2003)035[0091:SPIOSB]2.0.C0;2

This Article is brought to you for free and open access by the Department of Geology and Geophysics at LSU Digital Commons. It has been accepted for inclusion in Faculty Publications by an authorized administrator of LSU Digital Commons. For more information, please contact ir@lsu.edu. 


\section{Authors}

Michael N. Gooseff, J. E. Barrett, Peter T. Doran, Andrew G. Fountain, W. Berry Lyons, Andrew N. Parsons, Dorota L. Porazinska, Ross A. Virginia, and Diana H. Wall 
Portland State University

PDXScholar

$1-1-2003$

\section{Snow-Patch Influence on Soil Biogeochemical Processes and Invertebrate Distribution in the McMurdo Dry Valleys, Antarctica}

Michael N. Gooseff

John E. Barrett

Peter T. Doran

Andrew G. Fountain

Portland State University, andrew@pdx.edu

W. Berry Lyons

See next page for additional authors

Follow this and additional works at: https://pdxscholar.library.pdx.edu/geog_fac

Part of the Biogeochemistry Commons

Let us know how access to this document benefits you.

\section{Citation Details}

Gooseff, Michael N, J E Barrett, Peter T Doran, Andrew G Fountain, W Berry Lyons, Andrew N Parsons, Dorota L Porazinska, Ross A Virginia, and Diana H Wall. 2003. Snow-Patch Influence on Soil Biogeochemical Processes and Invertebrate Distribution in the McMurdo Dry Valleys, Antarctica. Arctic Antarctic and Alpine Research 35, no. 1: 91-99.

This Article is brought to you for free and open access. It has been accepted for inclusion in Geography Faculty Publications and Presentations by an authorized administrator of PDXScholar. Please contact us if we can make this document more accessible: pdxscholar@pdx.edu. 


\section{Authors}

Michael N. Gooseff, John E. Barrett, Peter T. Doran, Andrew G. Fountain, W. Berry Lyons, Andrew N.

Parsons, Dorota L. Porazinska, Ross A. Virginia, and Diana H. Wall 


\section{Snow-Patch Influence on Soil Biogeochemical Processes and Invertebrate Distribution in the McMurdo Dry Valleys, Antarctica}

Michael N. Gooseff,

J. E. Barrett, ${ }^{2}$

Peter T. Doran, ${ }^{3}$

Andrew G. Fountain, ${ }^{4}$

W. Berry Lyons, ${ }^{5}$

Andrew N. Parsons, ${ }^{6}$

Dorota L. Porazinska, ${ }^{6}$

Ross A. Virginia, ${ }^{2}$ and

Diana H. Wall ${ }^{6}$

${ }^{1}$ Institute of Arctic and Alpine Research, University of Colorado, Boulder, Colorado 80309-0450, U.S.A.

Present address: Department of Aquatic, Watershed, and Earth Resources, Utah State University, Logan, Utah 84322-5210, U.S.A. gooseff@cnr.usu.edu

${ }^{2}$ Environmental Studies Program, Dartmouth College, 6182 Steel Hall, Hanover, New Hampshire 03755,

U.S.A.

${ }^{3}$ Department of Earth and

Environmental Sciences, University of Illinois at Chicago, 845 W. Taylor

Street, Chicago, Illinois 60607-7059,

U.S.A.

${ }^{4}$ Department of Geology, Portland

State University, Portland, Oregon

97207-0751, U.S.A.

${ }^{5}$ Byrd Polar Research Center, Ohio

State University, 1090 Carmack Rd,

Scott Hall, Columbus, Ohio 43210-

1002, U.S.A.

${ }^{6}$ Natural Resource Ecology

Laboratory, Colorado State University,

Fort Collins, Colorado 80523-1499,

U.S.A.

\begin{abstract}
The McMurdo Dry Valleys is the largest of the ice-free areas in Antarctica. Precipitation events in excess of $1 \mathrm{~cm}$ of snow accumulation are rare. During the winter, snow is transported by strong katabatic winds blowing from the polar plateau, and deposited into the lee of topographic features (e.g., stream channels and other topographic depressions). At the start of the austral summer (early October), as much as $10 \%$ of the valley soils may be covered by distributed snow patches. Because liquid water is the primary driver of biological, physical, and chemical processes in this polar desert, quantifying fluxes of water from snow patches is important to understanding the influence of hydrology on soil biology and nutrient cycling. During the austral summer of 1999-2000, four snow patches that had developed during the previous winter in Taylor Valley were studied. We measured snow-patch area, depth, and snow water equivalent, as well as subnivian (under snow) and nearby exposed (control) soil temperature, light intensity, soil moisture, invertebrate abundance, soil organic matter content, and 95-d labile pools of $\mathrm{C}$ and N. Subnivian soils differed from exposed soils being as much as $26.8^{\circ} \mathrm{C}$ colder than exposed soils; average soil moisture ranging from 6.9 to $13.6 \%$ compared to $0.4 \%$ in exposed soils; soil invertebrate populations exceeding 7900 individuals $\mathrm{kg}^{-1}$ dry soil versus less than 1200 individuals $\mathrm{kg}^{-1}$ dry soil in exposed soils; and soil invertebrate species richness values greater than 2 taxa, compared to 1.3 taxa in exposed soils. The results of this study show that these seasonal, sparse snow patches may be an important source of moisture and control habitat of soil ecosystems in this extreme environment.
\end{abstract}

\section{Introduction}

The Dry Valleys are an ice-free polar desert region near the Ross Sea (Fig. 1). The Dry Valleys range in elevation from sea level to $800 \mathrm{~m}$ a.s.1. and are bordered by mountain ranges, up to nearly $2000 \mathrm{~m}$ a.s.1. During the austral summer, light intensity and climate vary with elevation and solar aspect, with north-facing ground receiving more solar energy than southernaspect ground. Because precipitation is so low (approximately $10 \mathrm{~cm}$ water equivalent annually: Keys, 1980) and most accumulation of snow generally ablates within a few hours after a summer snowfall (Campbell et al., 1998), the soils of the Dry Valleys typically receive little moisture. During the austral winter, snow is transported from the polar plateau during strong katabatic events that generally blow downvalley. The windblown snow accumulates across the landscape in topographic depressions, leeward of the prevailing wind or along glacier faces. These snow patches ablate (sublimate and/or melt) slowly during the austral summer and may provide a source of moisture for a limited duration to the soils and biota beneath. While ablation rates are quantified for glaciers $(10$ to $15 \mathrm{~cm}$ $\mathrm{yr}^{-1}$ : Fountain et al., 1998; Lewis et al., 1998), and for the permanent ice covers on the lakes $\left(30\right.$ to $35 \mathrm{~cm} \mathrm{yr}^{-1}$ : Clow et al., 1988; Chinn, 1993), ablation and melt rates have not been quantified for snow patches on the soils. However, if snowmelt provides moisture to the underlying (subnivian) soils, soil water is not present for very long. Campbell et al. (1998) monitored gravimetric soil water in the surface soils $(0-5 \mathrm{~cm})$ and 


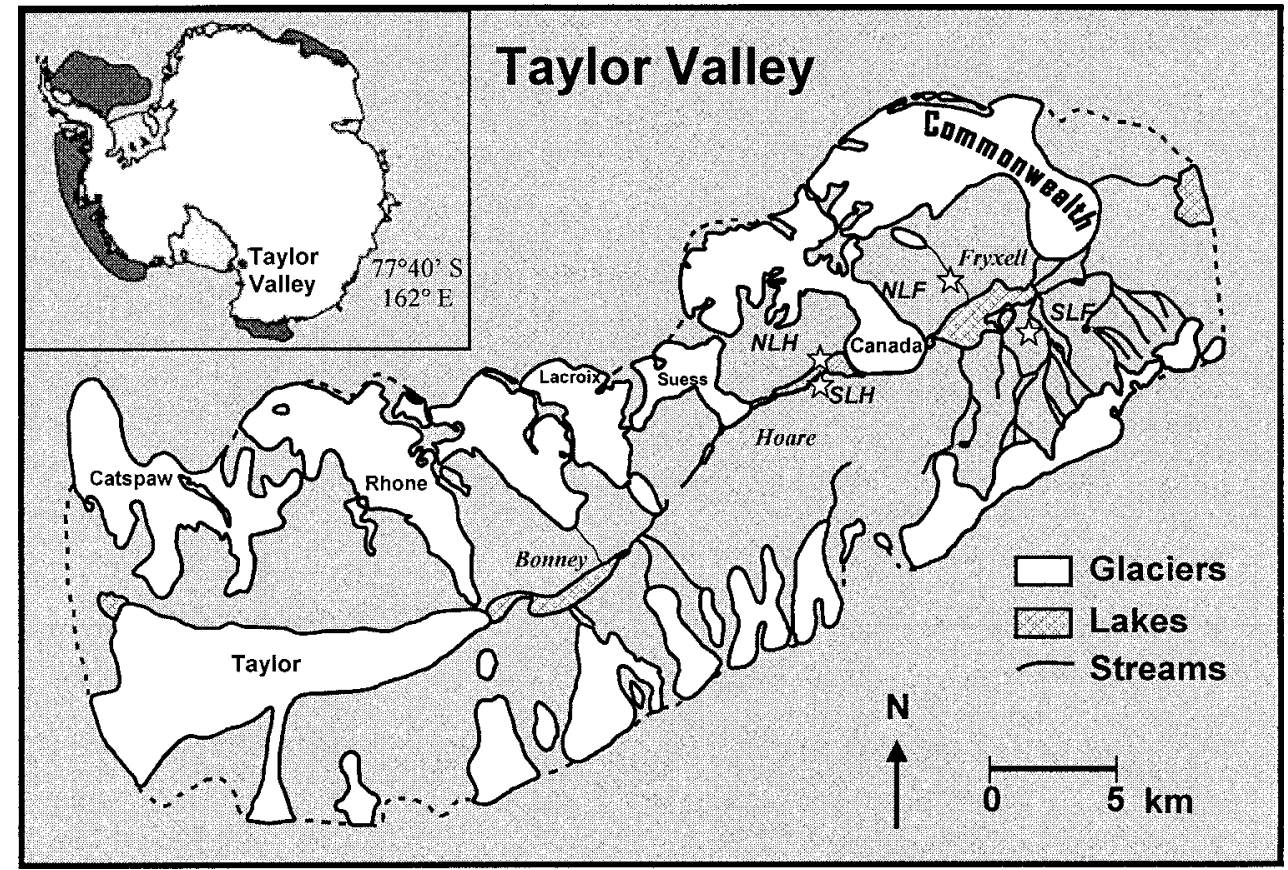

FIGURE 1. Map of Taylor Valley, with stars showing locations of experimental snow patches. Antarctic location map denotes location of some ice shelves and Taylor Valley. reported moisture losses from 12 to $5 \%$ in $4 \mathrm{~d}$ and 5 to $<1 \%$ over the next $10 \mathrm{~d}$.

The availability and duration of soil moisture in antarctic soils effects a range of processes: material transport (eolian deposition of marine aerosols, including nutrients), physico-chemical soil weathering, distribution of soil invertebrate communities, and for microbes, nutrient cycling. Transport of soil organic matter vertically within soil layers, by microscopic organisms, percolation, or runoff, is common in temperate soils with abundant soil moisture. In the Dry Valleys, the low moisture availability and rapid sublimation rates of soil moisture limits vertical material transport within soil layers (Claridge et al., 1999). Eolian distribution of organic material is thought to be an important mechanism for material transport in the dry climate of the Dry Valleys (Friedmann et al., 1993; Moorhead et al., 1999; Fritsen et al., 2000; Lancaster, 2002) facilitated perhaps by katabatic events.

Previous studies in alpine and northern high-latitude tundra regions have found that the temporal and spatial distribution of snow controls biogeochemical processes in soils because snow acts as a physical barrier, insulator, and source of water (Williams et al., 1998; Brooks and Williams, 1999; Walker et al., 1999). Snow can also be a source of inorganic nitrogen (Bowman, 1992). Further, snowpack distribution has also been shown to control subnivian terrestrial plant communities (Seastedt and Vaccaro, 2001). The Dry Valleys lack aboveground terrestrial plants, which is a clear contrast to the alpine and high-latitude tundra sites of these previous experiments. Nonetheless, snow cover on any landscape insulates underlying soils from dry atmospheric deposition of nutrients and salts, and from direct heat exchange with the atmosphere. Snow cover may have a similar function in Dry Valley soils.

The distribution of soil organisms in Antarctica is influenced by soil water availability (Kennedy, 1993), but in the driest soils of the Dry Valleys, a combination of salinity, soil organic carbon, and to a lesser degree, soil moisture, controls the distribution of biotic communities (Freckman and Virginia, 1998; Virginia and Wall, 1999; Courtright et al., 2001) and biogeochemical cycling (Treonis et al., 1999; Barrett et al., 2002).
Therefore, the distribution of seasonal snow patches may be important for predicting controls on soil biodiversity and ecosystem functioning, as snow patches may provide moisture, insulate soils, and hinder the deposition of marine aerosols.

Studies of soil and rock weathering in the Dry Valleys have found that weathering is generally slow, except in locations that are in contact with water (Lyons and Mayewski, 1993; Matsuoka, 1995; Gooseff et al., 2002). Moisture provided by snow patches may cause dissolution of salts in underlying minerals in soils, providing additional nutrients to the soil habitat (e.g., orthophosphate). Soils of the Dry Valleys occur on poorly developed glacial tills, typically composed of 95 to $99 \%$ sand, with high salt concentrations, and $\mathrm{pH}$, and low organic matter content (0.01-0.03\% organic C by weight, Campbell and Claridge, 1987; Burkins et al., 2000; Fritsen et al., 2000). In particular, the Taylor Valley soils studied here are classified as Pergelic Cryorthents (Campbell and Claridge, 1987) and more recently under the Gelisol order as mixed Nitric Anhyturbels and mixed Glacic Anhyturbels (Bockheim, 1997; Beyer et al., 1999).

We hypothesized that snow-cover distribution controls the aspects of the soil environment (moisture, temperature, chemistry) which determine the distribution of soil invertebrates. We examined the physical characteristics of accumulated snow patches across the landscape, soil biogeochemical conditions, and invertebrate populations in soils underneath and adjacent to snow patches. These characteristics were analyzed in relation to snow-patch morphology; that is, samples were collected along the expected snow-patch depositional gradient. We then compared soil habitat conditions and biodiversity underneath snow patches to soils that are not covered by snow for more than a day. Throughout this paper, we refer to soil sample sites underneath the snow patches as subnivian, even after the snow patch has disappeared. Soil sample sites outside the snow patches (as a control) will be referred to as exposed.

\section{Methods}

\section{FIELD LOCATION AND SAMPLING}

This study was conducted in Taylor Valley $\left(77^{\circ} 40^{\prime} \mathrm{S}\right.$, $163^{\circ} \mathrm{E}$ ), site of the U.S. National Science Foundation McMurdo 
TABLE 1

Sampling and measurement schedule at the experimental snow patches for 1999-2000 summer

\begin{tabular}{|c|c|c|c|c|}
\hline \multirow[b]{2}{*}{ Date } & \multicolumn{4}{|c|}{ Sampling or Measurement Made } \\
\hline & $\begin{array}{c}\text { Snow core } \\
\text { sample taken }\end{array}$ & $\begin{array}{l}\text { Soil samples } \\
\text { taken }\end{array}$ & $\begin{array}{l}\text { Snow depth } \\
\text { measurements }\end{array}$ & $\begin{array}{c}\text { Snow-patch } \\
\text { outline flagged }\end{array}$ \\
\hline 27 October 1999 & NLH & NLH & $\mathrm{NLH}$ & NLH \\
\hline 28 October 1999 & NLF & NLF & NLF & NLF \\
\hline 29 October 1999 & SLH & SLH & SLH & SLH \\
\hline 02 November 1999 & SLF & SLF & SLF & SLF \\
\hline 13 November 1999 & & & & NLH, SLH \\
\hline 19 November 1999 & & & & NLF \\
\hline 22 November 1999 & SLH & SLH & SLH & SLH \\
\hline 23 November 1999 & NLH & NLH & NLH & $\mathrm{NLH}$ \\
\hline 27 November 1999 & & NLF & NLF & NLF \\
\hline 28 November 1999 & NLF, SLF & SLF & SLF & SLF \\
\hline 08 December 1999 & NLH, SLH & NLH, SLH & NLH, SLH & NLH, SLH \\
\hline 14 December 1999 & & SLF & SLF & \\
\hline 20 December 1999 & NLF & NLF & NLF & SLF \\
\hline 25 December 1999 & & NLH, SLH & $\mathrm{NLH}, \mathrm{SLH}^{\mathrm{a}}$ & NLF \\
\hline 04 January 2000 & & & $\mathrm{NLH}^{\mathrm{a}}$ & NLH \\
\hline 05 January 2000 & & & & NLF \\
\hline 13 January 2000 & & & & $\mathrm{SLF}^{\mathrm{a}}$ \\
\hline 25 January 2000 & & & & NLF \\
\hline
\end{tabular}

a Represents first observation of complete absence of snow. See text for explanation of site abbreviations.

Dry Valleys Long-Term Ecological Research project. The valley is approximately $30 \mathrm{~km}$ long, with $105 \mathrm{~km}^{2}$ of the land surface as soil (Burkins et al., 2001). During the 1999-2000 austral summer, we selected four snow-patch locations representing varying light intensities throughout a 24-h period: North Shore of Lake Hoare $\left(162^{\circ} 52.3^{\prime} \mathrm{E}, 77^{\circ} 37.6^{\prime} \mathrm{S}\right)(\mathrm{NLH})$, South Shore of Lake Hoare $\left(162^{\circ} 54.1^{\prime} \mathrm{E}, 77^{\circ} 37.9^{\prime} \mathrm{S}\right)$ (SLH), Von Guerard Stream bank $\left(163^{\circ} 15.2^{\prime} \mathrm{E}, 77^{\circ} 36.7^{\prime} \mathrm{S}\right)$ on the south side of Lake Fryxell (SLF), and Huey Creek stream bank $\left(163^{\circ} 07.4^{\prime} \mathrm{E}, 77^{\circ} 36.2^{\prime} \mathrm{S}\right)$ on the north side of Lake Fryxell (NLF) (Fig. 1). NLH receives daily topographic shading during the afternoon and evening hours, whereas SLH has a northerly aspect and receives very little topographic shading until late at night, from mid-October to February (Dana et al., 1998). These two sites are at roughly the same elevation and experience approximately the same climate variability (e.g., wind and air temperature). The SLF site has a northeast aspect on the broad western bank of Von Guerard Stream and receives no topographic shading during the austral summer. The NLF site had a southeast aspect and was situated away from large topographic shading sources.

In late October 1999, two Onset HOBO H8 Pro Series temperature data loggers (Onset Computer Corp., Pocasset, MA) with external thermistors $\left( \pm 0.4^{\circ} \mathrm{C}\right)$ were placed at each of the four snow-patch sites to monitor soil temperature. At each snow patch, one temperature sensor was placed underneath the subnivian soil, and the other was placed in nearby exposed soil, each to a depth of $<1 \mathrm{~cm}$. At NLH and SLH, two light intensity (LI) data loggers (Onset Stowaway model SLA08) were also deployed. At each of the two snow patches, one LI data logger was placed under the snow patch, and one was placed outside the snow patch. The LI data loggers recorded data from the first visit to the snow patch sites (27 October 1999 at NLH and 29 October 1999 at SLH) to 23 January 2000. In addition, a variety of physical and biological parameters were measured for each snow patch on an irregular schedule (Table 1).

\section{SNOW SAMPLING}

One method of detecting snowmelt is to measure changing snow water equivalent (SWE) and changing snow depth. Decreases in snow depth that are occur faster than decreases in SWE at the same point (thus snow density increases) would suggest some liquid snowmelt becoming incorporated into the snow patch. At each snow patch, one core of the entire snow-patch thickness was taken prior to excavation of snow for soil sampling. The snow cores were collected by vertically pushing a 4.5-cm-diameter lexan tube into the snow. The depth of uncompressed snow immediately surrounding the tube was measured and the extracted snow placed in large sterile Whirl-Pak ${ }^{\circledR}$ (NASCO Inc., Fort Atkinson, WI) polyethylene bags for slow, roomtemperature (approximately $15^{\circ} \mathrm{C}$ ) melting in a field camp laboratory following collection. Snow density was calculated from the quotient of the mass of melted snow and the volume of snow extracted. Snow depths were consistently measured at 9 to 12 points across the snow patch. The area covered by the snow patch was estimated at each visit by placing flags around the perimeter and comparing to the perimeter at the previous visit. During the final visit all flags were surveyed using a Wild Tachymat total station model 1010 (Leica Geosystems, Switzerland). Survey data were later entered into a geographical information system software package (ArcView v.3.2, ESRI, Redlands, CA) to compute accurate snow-patch area changes. With the exception of the NLF snow patch, all snow patches disappeared by the end of the study in late January.

\section{INVERTEBRATE ANALYSES}

At each snow-patch site, four sampling sites along a linear transect across the snow patch were established, from upvalley to downvalley (in the direction of the snow-depositing winter katabatic winds): one control site that was approximately $1 \mathrm{~m}$ from the edge of the snow patch, upvalley of the lee (exposed), and three subnivian sites (subnivian 1,2, and 3). We expected 
differences in snow ablation rates and underlying soil moisture based on the location within the snow patch. Beginning in late October (time 0), soil samples were collected with a small trowel to a depth of approximately $5 \mathrm{~cm}$. For each soil sample, trowels that had been previously rinsed with deionized water and dried were used. Subnivian soil samples were obtained by digging through the snow from the top of the snow patch. An articulating ladder (made of three sections capable of locking in various angles) was used to access the middle of the snow patch, with minimal disturbance to the snow. The overlying snow that had been removed was retained so that it could be replaced after the soil samples were collected. Soil samples were placed in sterile polyethylene (Whirl-Pack ${ }^{\circledR}$ ) bags and transported to the lab frozen at approximately $-2^{\circ} \mathrm{C}$. Samples were later thawed at $4^{\circ} \mathrm{C}$ and immediately processed. Subsamples of $100 \mathrm{~g}$ were used for soil invertebrate extractions by the modified sugar flotation method (Freckman and Virginia, 1993), and an additional 30-g subsample was oven dried at $105^{\circ} \mathrm{C}$ for $24 \mathrm{~h}$ for gravimetric soil moisture determination (Gardner, 1986). Soil invertebrates were identified and enumerated, life stage determined, and presented per kg dry weight of soil. Because of insufficient amount of soil from one of the subnivian NLF soil sites (subnivian 3), on 28 October 1999 only $70 \mathrm{~g}$ of soil was used for invertebrate extraction.

Invertebrate data were $\log (x+1)$ transformed, and subjected to analysis of variance within snow patches as replications (4), location within each snow patch (4), and time of sampling (3) as main factors. Correlation analysis was used to determine presence of relationships between nematode and soil variables.

\section{SOIL ANALYSIS AND INCUBATIONS}

We estimated soil salinity by measuring the electrical conductivity of a 1:5 soil solution of sieved (2-mm sieve) soil in deionized water (Rhoades, 1982). Electrical conductivity was measured using a Corning 311 conductivity meter. Soil pH was measured in a saturated paste (1:2 soil in deionized water) with an Orion model 720A pH meter (McLean, 1982). A 15-g subsample was used to determine initial soil $\mathrm{NO}_{3}{ }^{-} \mathrm{N}$ and $\mathrm{NH}_{4}{ }^{+}-\mathrm{N}$ concentrations from a $2.0 \mathrm{M} \mathrm{KCl}$ extract on a Lachat Autoanalyzer (Keeney and Nelson, 1982). A subsample of each soil was analyzed for organic $\mathrm{C}$ and total $\mathrm{N}$ content with a Carlo Erba 1500 elemental analyzer (Carlo Erba, Milan, Italy) (Nelson and Sommers, 1982).

We conducted laboratory incubations of exposed and subnivian soils to estimate pools of mineralizable $\mathrm{C}$ and $\mathrm{N}$ in order to assess differences in the amount of potentially active organic matter among the landscape positions (i.e., exposed or subnivian). For each soil sample, approximately $100 \mathrm{~g}$ of oven-dried soil was placed in a $300-\mathrm{mL}$ glass jar with screw-top lid and brought up to $10 \%$ soil moisture content. A hole was drilled in each jar lid and a $\mathrm{CO}_{2}$ impermeable rubber septum was sealed onto the lid with silicon sealant. Soils were stored at $20^{\circ} \mathrm{C}$ for $95 \mathrm{~d}$. Each incubation vessel was sealed $48 \mathrm{~h}$ prior to sampling of the headspace gas. Gas samples $(10 \mathrm{~mL})$ were collected from the mason jar headspace above the soils with a gas-tight glass syringe at $t=3,9,18,29,39,54,65$, and $95 \mathrm{~d}$ and injected into a LI-COR 6200 Portable Photosynthesis System/Infra red gas analyzer (LI-COR Inc., Lincoln, NE) modified to measure $\mathrm{CO}_{2}$ concentrations of small gas volumes. Headspace $\mathrm{CO}_{2}$ concentrations were blank corrected and expressed as $\mu \mathrm{g} \mathrm{C} \mathrm{g} \mathrm{soil}{ }^{-1}$ $\mathrm{d}^{-1}$ according to ideal gas behavior (Robertson et al., 1999). At the end of the incubations (day 95), approximately $20 \mathrm{~g}$ of ovendry weight equivalent soil was extracted in $2 \mathrm{M} \mathrm{KCl}$ and ana-
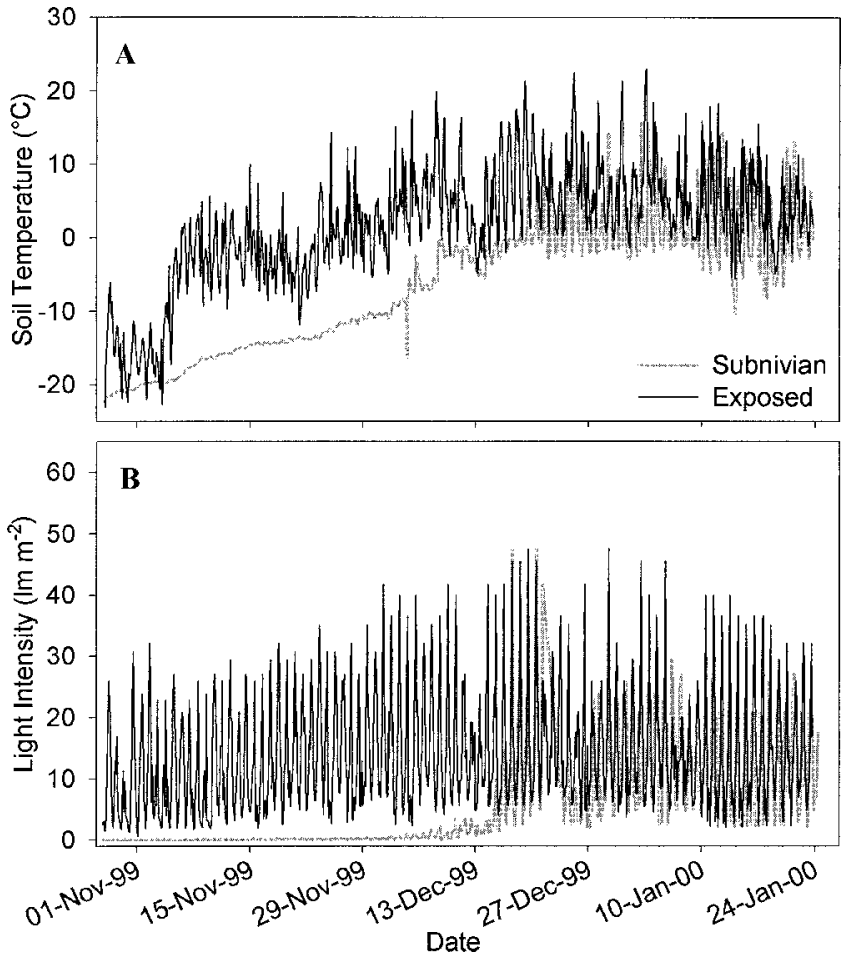

FIGURE 2. Exposed and subnivian (A) soil temperature, and (B) light intensity at NLH snow patch.

lyzed for inorganic $\mathrm{N}$ as described above, to determine potential net $\mathrm{N}$ mineralization and nitrification. Net $\mathrm{N}$ mineralization and nitrification were calculated as the difference between day 95 and initial concentrations of inorganic $\mathrm{N}$ (ammonium + nitrate) and nitrate, respectively.

\section{Results}

\section{SNOW PROPERTIES AND SOIL TEMPERATURES}

Snow patches had a significant influence over soil microclimate and physical properties during the 1999 austral summer. Temperature and light intensity results for NLH are shown in Figure 2; data from other sites are summarized in Table 2. Subnivian soil temperatures were generally colder than exposed soil temperatures and did not exhibit much diel fluctuation compared to exposed soil temperatures prior to overlying snow ablation. As the snow patch ablated at all four sites, a diel pattern of soil temperatures appeared, resulting from the decreased insulating effects of the snow. Overall, NLH exposed soil temperatures exhibited lower peaks than SLH $\left(23.2^{\circ} \mathrm{C}\right.$ and $29.2^{\circ} \mathrm{C}$, respectively), and were colder on average than SLH $\left(1.6 \pm 8.0^{\circ} \mathrm{C}\right.$ and 2.9 $\pm 9.0^{\circ} \mathrm{C}$, respectively). Prior to snow-patch disappearance, there were substantial temperature differences between the exposed and subnivian sites, while after disappearance, little difference existed. Soil temperatures were generally higher in the exposed sites than the subnivian sites because the relatively high albedo of the snow greatly reduces solar heating compared to snow-free soils. All soil temperatures generally follow the seasonal air temperature increase from October to December.

Light intensity (LI) was less than 1 to $21 \mathrm{~m} \mathrm{~m}^{-2}$ at the subnivian snow sensor at the NLH and SLH sites early in the season (Fig. 2). The NLH exposed LI data reflected the seasonal variation of sunlight exposure at that site with increasing LI to a peak around the winter solstice. During the increasing portion of that trend, in mid-December, the subnivian LI meter became 
TABLE 2

Summary of soil temperature and light intensity data for snow patches studied

\begin{tabular}{|c|c|c|c|c|}
\hline & NLH & SLH & NLF & SLF \\
\hline $\begin{array}{l}\text { Minimum, Mean, and Maximum exposed } \\
\text { soil temperature, [std. dev.], }\left({ }^{\circ} \mathrm{C}\right)\end{array}$ & $\begin{array}{l}-24.9,1.6 \\
23.2,[8.0]\end{array}$ & $\begin{array}{l}-23.5,2.9 \\
29.2,[9.0]\end{array}$ & N/A & $\begin{array}{c}-20.2,1.2 \\
14.8,[5.7]\end{array}$ \\
\hline $\begin{array}{l}\text { Minimum, Mean, and Maximum subnivi- } \\
\text { an soil temperature, [std. dev.], }\left({ }^{\circ} \mathrm{C}\right)\end{array}$ & $\begin{array}{c}-21.8,-6.5 \\
16.5,[8.5]\end{array}$ & N/A & $\begin{array}{c}-22.9,-6.4 \\
10.9,[7.6]\end{array}$ & $\begin{array}{c}-21.0,-3.5, \\
15.7,[8.6]\end{array}$ \\
\hline $\begin{array}{l}\text { Minimum, Mean, and Maximum exposed } \\
\text { light intensity, [std. dev.], }\left(1 \mathrm{~m} \mathrm{~m}^{-2}\right)\end{array}$ & $\begin{array}{c}0.6,14.3 \\
64.4,[10.1]\end{array}$ & $\begin{array}{l}0.5,13.5, \\
45.5,[7.7]\end{array}$ & N/A & N/A \\
\hline $\begin{array}{l}\text { Minimum, Mean, and Maximum subnivi- } \\
\text { an light intensity, [std. dev.], }\left(\mathrm{lm} \mathrm{m}^{-2}\right)\end{array}$ & $\begin{array}{r}0.0,5.5 \\
56.5,[8.0]\end{array}$ & $\begin{array}{r}0.0,11.5 \\
64.4,[11.2]\end{array}$ & N/A & N/A \\
\hline
\end{tabular}

uncovered and tracked the exposed meter closely. The SLH subnivian LI meter is uncovered about $20 \mathrm{~d}$ prior to the NLH subnivian LI sensor. The SLH subnivian LI meter recorded a trend similar to that recorded by the exposed SLH LI meter, but with a much larger diel LI cycle. Subnivian LI values were lower on average than exposed LI values (Table 2).

Snow-depth data are presented in Figure $3 \mathrm{~A}$ as mean and standard deviation. Mean snow depths at the beginning of the study ranged from 0.2 to $0.6 \mathrm{~m}$. Snow depths were quite variable, as standard deviations ranged from under 0.1 to $0.3 \mathrm{~m}$. Snow depths showed a decreasing trend with time, and snow patches disappeared completely at NLH by 4 January 2000, at SLH by 25 December 1999, and at SLF by 13 January 2000
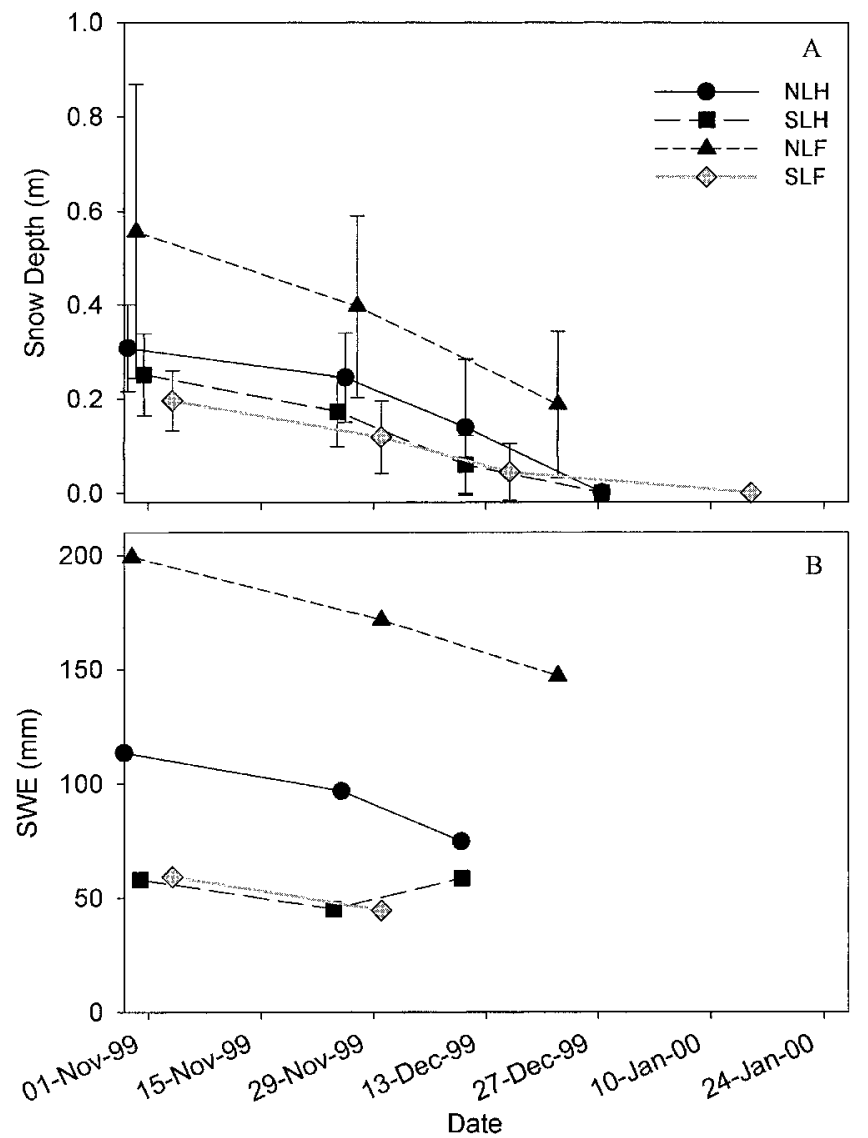

FIGURE 3. (A) Snow-depth data is reported as a mean of 9 to 12 measurements for a particular date, error bars \pm 1 standard deviation from the mean, and $(B)$ snow water equivalent (SWE) data from point measurements.
(Table 1). At the NLF snow patch, complete ablation did not occur.

Figure 3B presents the SWE data for each of the snow patches throughout the season. Snow water equivalent values generally decreased throughout the season for all but the NLH snow patch, and snow density generally increased (data not shown). This result suggests that some melt may have occurred within or at the top of the snow patch. Of course, snow density and SWE data are dependent on the exact location of the snow sample, which was in the same vicinity within the snow patch for each snow core sample. Table 3 presents the loss of snowpatch area throughout the season. It appears that the fastest rates of loss occurring at the north-facing snow patches, SLF and SLH.

\section{SOIL BIOGEOCHEMICAL PROPERTIES}

Soil moisture results are presented here as a mean of each sampling location for each of the four snow patches (Table 4). Soil moisture content varied markedly, from less than $1 \%$ up to

TABLE 3

Snow-patch area loss rates

\begin{tabular}{|c|c|c|}
\hline Location/Date & Area $\left(\mathrm{m}^{2}\right)$ & $\begin{array}{l}\text { Rate of Loss } \\
\qquad\left(\mathrm{m}^{2} \mathrm{~d}^{-1}\right)\end{array}$ \\
\hline \multicolumn{3}{|l|}{ NLH } \\
\hline 27 October 1999 & 67.85 & \\
\hline 13 November 1999 & 56.8 & 0.65 \\
\hline 23 November 1999 & 48.9 & 0.79 \\
\hline 08 December 1999 & 30.5 & 1.23 \\
\hline 25 December 1999 & 0.46 & 1.77 \\
\hline \multicolumn{3}{|l|}{ SLH } \\
\hline 29 October 1999 & 126.11 & \\
\hline 13 November 1999 & 103.04 & 1.54 \\
\hline 23 November 1999 & 82.37 & 2.07 \\
\hline 08 December 1999 & 33.64 & 3.25 \\
\hline \multicolumn{3}{|l|}{ NLF } \\
\hline 28 October 1999 & 164.7 & \\
\hline 27 November 1999 & 157.81 & 0.23 \\
\hline 20 December 1999 & 140.37 & 0.76 \\
\hline 05 January 2000 & 90.52 & 3.12 \\
\hline 25 January 2000 & 60.01 & 1.53 \\
\hline \multicolumn{3}{|l|}{ SLF } \\
\hline 02 November 1999 & 192.16 & \\
\hline 28 November 1999 & 98.3 & 3.61 \\
\hline 14 December 1999 & 13.31 & 5.31 \\
\hline
\end{tabular}


TABLE 4

Mean biogeochemical properties of soils collected at an exposed site and three subnivian sites in Taylor Valley, Antarctica

\begin{tabular}{|c|c|c|c|c|}
\hline \multirow[b]{2}{*}{ Variable } & \multirow[b]{2}{*}{ Exposed } & \multicolumn{3}{|c|}{ Sampling Position } \\
\hline & & Subnivian 1 & Subnivian 2 & Subnivian 3 \\
\hline $\mathrm{pH}$ & 9.4 & 9.3 & 9.4 & 9.4 \\
\hline Electrical conductivity $\left(\mu \mathrm{S} \mathrm{cm}^{-1}\right)$ & 116 & 61 & 44 & 57 \\
\hline Average soil moisture (\%) & $0.4^{\mathrm{a}}$ & $6.9^{\mathrm{b}}$ & $13.6^{\mathrm{b}}$ & $7.7^{\mathrm{b}}$ \\
\hline Soil organic carbon ( $\mathrm{mg} \mathrm{C} \mathrm{g}^{-1}$ soil) & 0.41 & 0.41 & 0.68 & 0.40 \\
\hline Total soil nitrogen ( $\mathrm{mg} \mathrm{N} \mathrm{g}^{-1}$ soil) & 0.059 & 0.053 & 0.091 & 0.055 \\
\hline Potential net $\mathrm{N}$ mineralization $\left(\mu \mathrm{g} \mathrm{N} \mathrm{g}^{-1}\right.$ soil d $\left.\mathrm{d}^{-1}\right)$ & $0.069^{\mathrm{a}}$ & $-0.020^{\mathrm{b}}$ & $-0.011^{\mathrm{b}}$ & $0.007^{\mathrm{b}}$ \\
\hline Potential nitrification $\left(\mu \mathrm{g} \mathrm{N} \mathrm{g}^{-1}\right.$ soil d $\left.{ }^{-1}\right)$ & $0.072^{\mathrm{a}}$ & $-0.011^{\mathrm{b}}$ & $0.022^{\mathrm{b}}$ & $0.0010^{\mathrm{b}}$ \\
\hline Potential C mineralization $\left(\mu \mathrm{g} \mathrm{C} \mathrm{g} \mathrm{soil}{ }^{-1} \mathrm{~d}^{-1}\right)$ & 1.31 & 0.89 & 0.52 & 0.47 \\
\hline 95-d C turnover $\left(\mathrm{d}^{-1}\right)$ & $0.31^{\mathrm{a}}$ & $0.11^{\mathrm{b}}$ & $0.10^{\mathrm{b}}$ & $0.11^{\mathrm{b}}$ \\
\hline
\end{tabular}

${ }^{a, b}$ Different letters denote significant differences in soil properties among sampling positions at $\alpha=0.05$.

$14 \%$ by weight (Table 4$)$. Soil moisture was significantly lower in the exposed sites (mean $=0.42 \%$ ) than the subnivian sites $($ mean $=9.38 \%)(P<0.01)$. In November, while snow patches were present, subnivian soil moisture was higher than exposed soil moisture content, and decreased significantly from a mean of $9.65 \%$ to $4.63 \%$ during the period of study $(P<0.05)$.

Although the mean electrical conductivity of exposed soils was higher than that for subnivian soils (Table 4), this trend was not statistically significant. Similarly, no significant differences in soil $\mathrm{pH}$ among positions sampled were observed (Table 4).

Soil organic matter concentrations from subnivian and exposed soils were comparable (Table 4), but the potentially mineralizeable pool of $\mathrm{N}$ was significantly greater in exposed soils $(P<0.01)$. Potential $\mathrm{C}$ turnover in exposed soils was three times
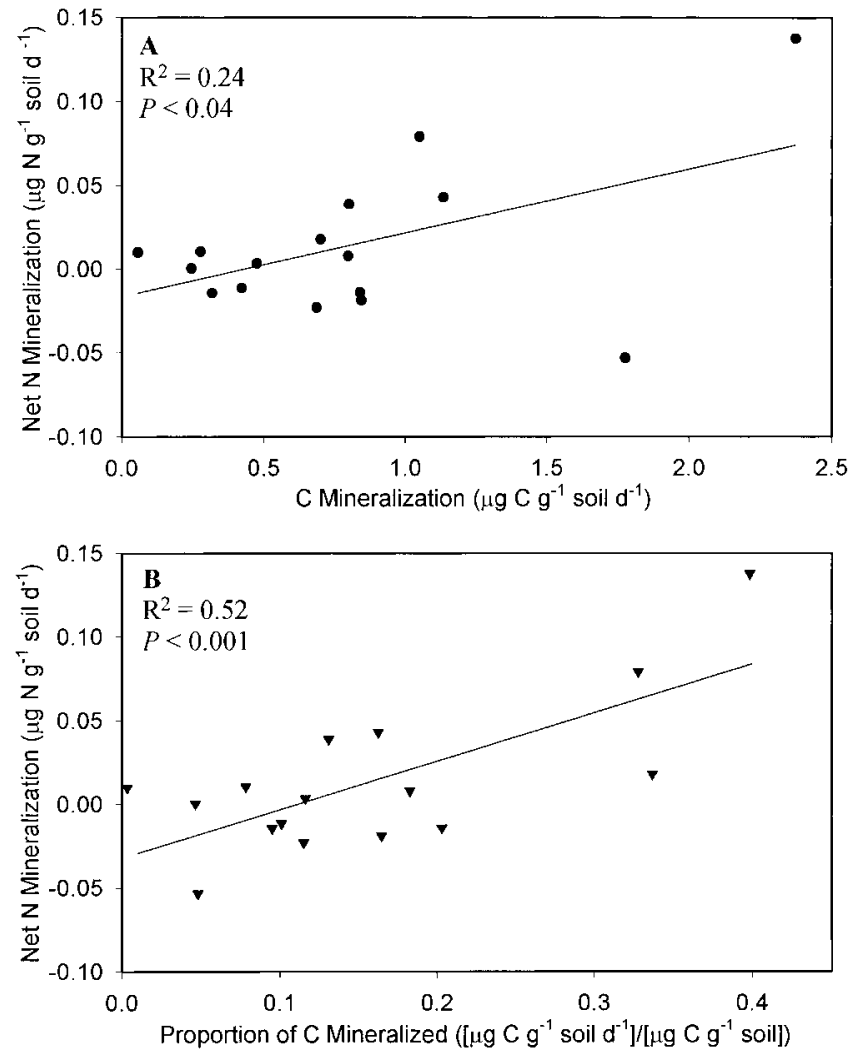

FIGURE 4. Scatter plots of (A) potential net $N$ mineralization vs. potential $C$ mineralization and $(B)$ net $N$ mineralization $v s$. proportion of $C$ mineralized. that of subnivian soils (Table 4) and potential nitrification and net mineralization in exposed soil sites were 3 to 10 times greater than levels of nitrification or net mineralization estimated for subnivian soils (Table 4). Standing pools of KCl-extractable soil nitrate concentrations were universally greater than ammonium concentrations (data not shown), and nitrification represented greater than $90 \%$ of the total net $\mathrm{N}$ mineralization in all soils (Table 4). C mineralization accounted for $24 \%$ of the variance in estimates of potential net $\mathrm{N}$ mineralization (Fig. 4A), and potential $\mathrm{C}$ turnover accounted for $52 \%$ of the variance in potential net $\mathrm{N}$ mineralization (Fig. 4B).

Potential $\mathrm{C}$ mineralization did not exhibit first order kinetics (constant proportional mass loss per unit time) over the 95-d soil incubations (Fig. 5). However, after $20 \mathrm{~d}$ of laboratory incubation, $\mathrm{C}$ mineralization from exposed soils could be reasonably described by a zero order model (constant loss of mass per unit time). There was a marked difference in the shape of the $\mathrm{C}$ mineralization curves and the amount of $\mathrm{C}$ mineralized between exposed and subnivian soils, reflecting much greater levels of labile $\mathrm{C}$ in exposed soils (Fig. 5).

\section{SOIL INVERTEBRATES}

Generally, subnivian soils maintained significantly more diverse soil communities, averaging 2.7 invertebrate taxa compared to 1.3 taxa in exposed soils. Invertebrate communities of exposed soils were composed of rotifers and the endemic nem-

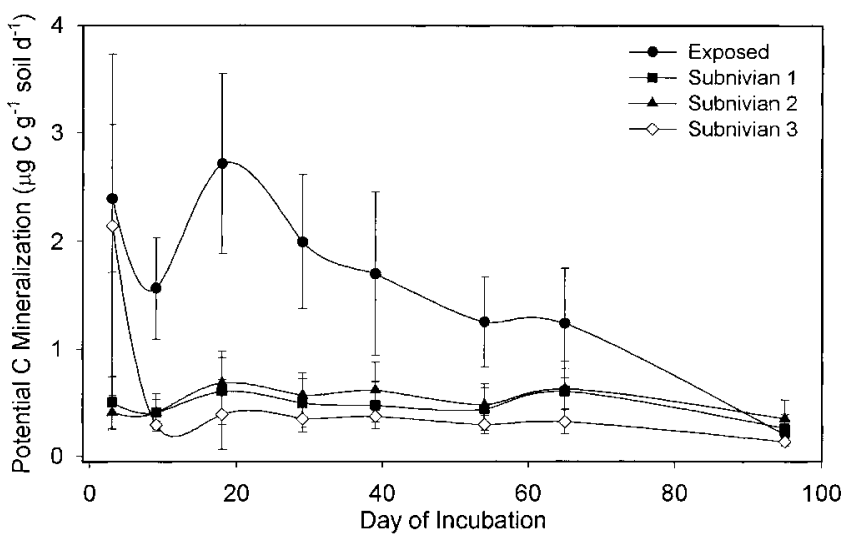

FIGURE 5. Plot of 95-d potential $C$ mineralization in soils collected from exposed and subnivian (1,2, and 3) soil sample sites at the four experimental snow patches in Taylor Valley, Antarctica. Error bars are \pm 1 standard error of the mean. 
TABLE 5

Abundance (mean numbers per $\mathrm{kg}$ dry soil) and richness (mean number of taxa) of soil invertebrates collected at one exposed and three subnivian sites for all snow patches (4) in Taylor Valley, Antarctica, over all sampling dates (3, thus $n=12)$

\begin{tabular}{lrrrr}
\hline \multicolumn{1}{c}{ Variable } & Exposed & Subnivian 1 & Subnivian 2 & Subnivian 3 \\
\hline Scottnema lindsayae & & & & \\
$\quad$ Living & 1057 & 779 & 1392 & 2007 \\
Dead & 49 & 242 & 415 & 395 \\
Total & 1113 & 1021 & 1816 & 2411 \\
Eudorylaimus antarcticus & & & & \\
Living & $0^{\mathrm{a}}$ & $50^{\mathrm{b}}$ & $45^{\mathrm{b}}$ & $48^{\mathrm{b}}$ \\
Dead & $0^{\mathrm{a}}$ & $20^{\mathrm{b}}$ & $28^{\mathrm{b}}$ & $21^{\mathrm{b}}$ \\
Total & $0^{\mathrm{a}}$ & $60^{\mathrm{b}}$ & $61^{\mathrm{b}}$ & $54^{\mathrm{b}}$ \\
Plectus antarcticus & & & & \\
Living & & & & \\
Dead & $0^{\mathrm{a}}$ & $199^{\mathrm{b}}$ & $0^{\mathrm{a}}$ & $0^{\mathrm{a}}$ \\
Total & $0^{\mathrm{a}}$ & $17^{\mathrm{b}}$ & $0^{\mathrm{a}}$ & $11^{\mathrm{b}}$ \\
Total nematodes & $0^{\mathrm{a}}$ & $256^{\mathrm{b}}$ & $0^{\mathrm{a}}$ & $11^{\mathrm{b}}$ \\
Rotifers & 1105 & 1194 & 1879 & 1873 \\
Tardigrades & 85 & 49 & 6079 & 78 \\
Richness & $0^{\mathrm{a}}$ & $0^{\mathrm{a}}$ & $41^{\mathrm{b}}$ & $72^{\mathrm{b}}$ \\
\hline
\end{tabular}

${ }^{a, b}$ Different letters denote significant differences in soil properties among sampling positions at $\alpha=0.05$.

atode species Scottnema lindsayae, but Eudorylaimus and Plectus nematode species and tardigrades were not found (Table 5). Subnivian soils had higher numbers of rotifers and tardigrades, compared to exposed soils, as well as populations of Scottnema, Eudorylaimus, and Plectus (Table 5). Total nematode abundance, and specifically Scottnema abundance, was greatest in subnivian soils, but this trend was not statistically significant (Table 5). While the abundance of the omnivorous-predaceous nematode Eudorylaimus was significantly greater in soils collected from beneath snow patches than in soils collected from outside the snow patch (Table 5), significantly higher densities of Plectus were present at subnivian sites 1 and 3 than exposed and subnivian site 2 . Living nematodes were more abundant than dead nematodes at all sample sites, with the exception of 11 dead Plectus individuals found in subnivian 3 samples, but no live individuals. Invertebrate densities were not influenced by time as no significant differences between invertebrate abundances from one sampling to the next were observed.

There were no relationships between Scottnema and Eudorylaimus abundances and soil moisture in subnivian and exposed soils, and only a marginally significant relationship between soil moisture and Plectus densities. Electrical conductivity of the soil accounted for almost $80 \%$ of the variance in total nematode abundance (Fig. 6). Additionally, there were no apparent relationships among invertebrate abundance and soil organic matter content or between invertebrate abundance and estimates of potential $\mathrm{C}$ and $\mathrm{N}$ mineralization $(P>0.1)$.

\section{Discussion}

As expected, snow cover insulated subnivian soils from direct atmospheric heat transfer and light (Fig. 2, Table 2). Subnivian soil temperatures were generally lower than exposed soil temperatures until snow ablation occurred, and were insulated from the diurnal swings in air temperature and solar radiation. This is not surprising, considering permafrost is generally found

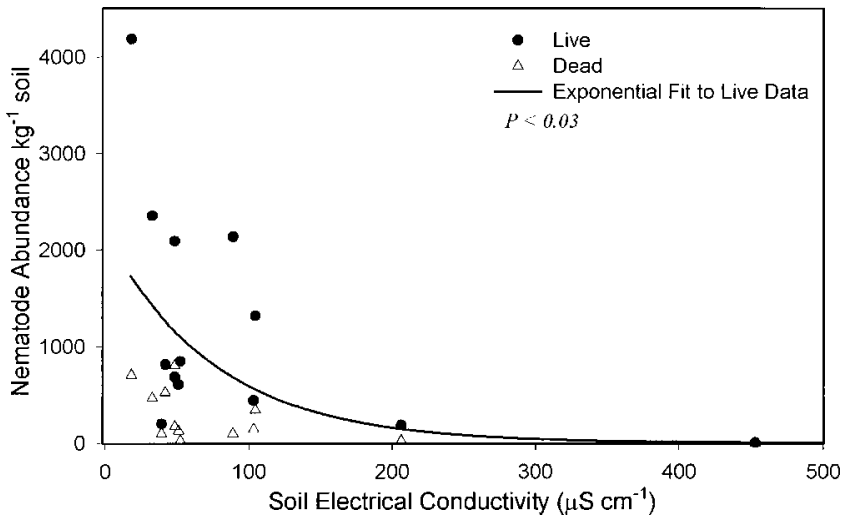

FIGURE 6. Plot of average nematode abundance vs. soil electrical conductivity. Exponential model fitted to live nematode abundance.

40 to $50 \mathrm{~cm}$ below the ground surface. Early in the summer, snow temperatures at the base of the snow patches are much lower than $0^{\circ} \mathrm{C}$, while exposed soil temperatures and air temperatures may be warmer than $0^{\circ} \mathrm{C}$. As a result, any melt or sublimation must have occurred at the edges of the snow patch, or at the surface. This is a clear contrast to temperate snow packs, which may melt continually, though slowly, throughout the winter, with snow-pack base temperatures usually at or near $0^{\circ} \mathrm{C}$. The $20-\mathrm{d}$ lag between the SLH and NLH subnivian LI data is not surprising given the afternoon topographic shading for the $\mathrm{NLH}$ site, which reduced the total solar radiation working to ablate the snow patch. However, we cannot rule out the possibility that the different depths at which the under-snow-patch LI sensors were placed contributed to the time lag.

Also as expected, subnivian soil moisture was significantly higher than exposed soil moisture. This is likely due to a small amount of melt that must be occurring at the bottom of the snow patch just before complete ablation, and the overlying snow patch preventing evaporative losses from the soil. Similar to the findings of Campbell et al. (1998), once the snow patches diminish in December, greater evaporation from the soils would be expected and soil moisture declines.

There were no differences in total organic matter content between soils collected from beneath and outside the snow patches. However, laboratory incubations indicate that there were considerable differences in the $\mathrm{C}$ and $\mathrm{N}$ mineralization potentials of these soils. Soils outside the snow patch contained high concentrations of labile $\mathrm{C}$ and $\mathrm{N}$ relative to soils beneath the snow patch, yet subnivian soils hosted relatively abundant and diverse biotic communities. This difference in the kinetic properties of the soil organic matter and invertebrate communities suggests that exposed soil biota are limited by water availability, while subnivian soil biota may be more limited by nutrient availability. For example, under laboratory conditions, labile $\mathrm{C}$ that is unavailable to soil biota because of water and physiological limitations in the field may be more readily utilized by soil microbes or invertebrates. Under field conditions, in contrast, subnivian soils maintain more favorable water availability and host higher invertebrate abundance which drives greater competition among soil biota for $\mathrm{C}$ substrate and soil resources in an environment where $\mathrm{C}$ inputs are limited by darkness.

Exposed soils may have a less favorable environment and lower invertebrate diversity (Table 5) but presumably have a positive, albeit low, $\mathrm{C}$ balance due to inputs of eolian-derived organic material (Moorhead et al., 1999) and direct C inputs through photosynthesis of soil algae. Reported estimates of $\mathrm{C}$ 
fixation by soil cryptoendolithic algae are low, $<1.0 \mathrm{~g} \mathrm{C} \mathrm{m}^{-2}$ $\mathrm{yr}^{-1}$ (Johnston and Vestal, 1991; Friedmann et al., 1993), but production by these similar types of communities in the soil may represent an important source of organic matter to microbial and invertebrate food webs. These differences in microclimate, organic matter availability and biodiversity between subnivian and exposed soils underscore the challenges to soil biota in this environment and identify some of the most relevant questions to Dry Valleys biogeochemistry, e.g., what sources of organic matter support contemporary soil food webs and how important are legacy sources of organic matter in structuring complex invertebrate communities?

\section{SOIL INVERTEBRATES}

Of the three species of nematodes that are widely spread across the Dry Valleys, Scottnema is the most abundant, and typically dominates soil communities (Freckman and Virginia, 1998; Virginia and Wall, 1999; Porazinska et al., 2002). The distribution of nematodes in the subnivian and exposed soils presented here is similar to the pattern found in previous studies, which established that the three nematode species have different soil habitat preferences (Freckman and Virginia, 1998; Porazinska et al., 2002). Scottnema does not appear to occur in wet soils, while Eudorylaimus and Plectus tend to be more abundant in wetter soils (Powers et al., 1998; Treonis et al., 1999; Freckman and Virginia, 1998; Courtright et al., 2001). We expected a strong relationship of nematode species distribution with moisture gradients as noted by Treonis et al. (1999) that Eudorylaimus and Plectus would be absent or few in drier exposed soils, and more abundant in moist subnivian soils. The results presented here for Eudorylaimus and Plectus abundances in subnivian and exposed soils are consistent with our expectations. That Scottnema abundance was not significantly different in moist and dry soils as noted by others (Powers et al., 1995) is further evidence of the greater tolerance of Scottnema to wider moisture ranges (Porazinska et al., 2002).

Considering that life cycles of antarctic nematodes are generally very long (years to decades: Overhoff et al., 1993; Porazinska et al., 2002), the consistently higher abundance of $E u$ dorylaimus under the snow patches suggests that the snow patches accumulate more or less from year to year in same locations. This result may also indicate that Eudorylaimus is consistently deposited by wind during strong katabatic events in these same locations/habitats throughout the year. The subnivian densities of Eudorylaimus were representative of other soil habitats across the Dry Valleys (Freckman and Virginia, 1997; Porazinska et al., 2002). Because dry soil habitats in the Dry Valleys are generally void of Eudorylaimus (Powers et al., 1998; Courtright et al., 2001), it is not surprising to observe higher densities of this nematode under, rather than outside, the snow patches. This result, as well as the general trend of lower invertebrate abundance in soils with higher electrical conductivity (Fig. 6), agrees with previous results of Treonis et al. (1999), Virginia and Wall (1999), and Courtright et al. (2001).

\section{Conclusions}

These data show that the distribution of snow patches has a distinct influence on the biogeochemical conditions in underlying soil, and presence of invertebrate distributions. Snow cover is a source of water to the soil directly underneath it. Further, these data suggest that there is a higher proportion of labile $\mathrm{C}$ in exposed soils than subnivian soils. One cause of this is that the snow patch acts as a physical barrier, keeping recently fixed $\mathrm{C}$ and/or eolian sources of organic matter out of the subnivian soils.

The soil biogeochemical conditions, in turn, directly affect the habitat for soil invertebrates. Greater abundance of Plectus and Eudorylaimus in subnivian soils compared to exposed soils suggests that the subnivian soils provide a more favorable habitat, and possibly, that the physical control of the wind-break, which causes snow to accumulate may contribute to maintenance of soil diversity.

\section{Acknowledgments}

The authors would like to thank Ethan Chatfield, Jon Mason, Carrie Olsen, and Jennifer Lawson for their assistance with fieldwork. Funding for this work was provided by the US National Science Foundation Office of Polar Programs, grant no. OPP 0096250.

\section{References Cited}

Barrett, J. E., Virginia, R. A., and Wall, D. H., 2002: Trends in resin and $\mathrm{KCl}$-extractable soil nitrogen across landscape gradients in Taylor Valley, Antarctica. Ecosystems, 5(3): 289-299.

Beyer, L., Bockheim, J. G., Campbell, I. B., and Claridge, G. G. C., 1999: Genesis, properties and sensitivity of Antarctic Gelisols. Antarctic Science, 11: 387-398.

Bockheim, J. G., 1997: Properties and classification of cold desert soils from Antarctica. Soil Science Society of America, 61: 224-231.

Bowman, W. D., 1992: Inputs and storage of nitrogen in winter snow patch in an alpine ecosystem. Arctic, Antarctic, and Alpine Research, 24: 211-215.

Brooks, P. D., and Williams, M. W., 1999: Snow pack controls on nitrogen cycling and export in seasonally snow-covered catchments. Hydrological Processes, 13: 2177-2190.

Burkins, M. B., Virginia, R. A., Chamberlain, C. P., and Wall, D. H., 2000: Origin and distribution of soil organic matter in Taylor Valley, Antarctica. Ecology, 81: 2377-2391.

Burkins, M. B., Virginia, R. A., and Wall, D. H., 2001: Organic carbon cycling in Taylor Valley, Antarctica: quantifying soil reservoirs and soil respiration. Global Change Biology, 7: $113-125$.

Campbell, I. B., and Claridge, G. G. C., 1987: Antarctica: Soils, Weathering Processes and Environment. Developments in Soil Science 16. Amsterdam: Elsevier. 368 pp.

Campbell, I. B., Claridge, G. G. C., Campbell, D. I., and Balks, M. R., 1998: The soil environment of the McMurdo Dry Valleys, Antarctica. In Priscu, J. C. (ed.), Ecosystem Dynamics in a Polar Desert: The McMurdo Dry Valleys, Antarctica. Antarctic Research Series, Vol. 72. American Geophysical Union: Washington, D.C., 323-335.

Chinn, T. J., 1993: Physical hydrology of the dry valley Lakes. In Green, W. J. and Friedmann, E. I. (eds.), Physical and Biogeochemical Processes in Antarctic Lakes, Antarctic Research Series, vol. 59. Washington, D.C., American Geophysical Union: $1-51$.

Claridge, G. G. C., Campbell, I. B., and Balks, M. R., 1999: Movement of salts in Antarctic soils: experiments using lithium chloride. Permafrost and Periglacial Processes, 10: 223-233.

Clow, G. D., McKay, C. P., Simmons, G. M., and Wharton, R. A. Jr., 1988: Climatological observations and predicted sublimatioin rates at Lake Hoare, Antarctica. Journal of Climate, 1: 715-728.

Courtright, E. M., Wall, D. H., and Virginia, R. A., 2001: Determining habitat suitability for soil invertebrates in an extreme environment: The McMurdo Dry Valleys, Antarctica. Antarctic Science, 13: 9-17.

Dana, G. L., Wharton, R. A., and Dubayah, R., 1998: Solar radiation in the McMurdo Dry Valleys, Antarctica. In Priscu, J. 
C. (ed.), Ecosystem Dynamics in a Polar Desert: The McMurdo Dry Valleys, Antarctica. Antarctic Research Series, Vol. 72. American Geophysical Union: Washington, D.C., 39-64.

Fountain, A. G., Dana, G. L., Lewis, K. J., Vaughn, B. H., and McKnight, D. M., 1998: Glaciers of the McMurdo Dry Valleys, Southern Victoria Land, Antarctica. In Priscu, J. C. (ed.), Ecosystem Dynamics in a Polar Desert: The McMurdo Dry Valleys, Antarctica. Antarctic Research Series, Vol. 72. American Geophysical Union: Washington, D.C., 65-76.

Freckman, D. W., and Virginia, R. A., 1993: Extraction of nematodes from Dry Valley Antarctic soils. Polar Biology, 13: 483-487.

Freckman D. W., and Virginia R. A., 1997: Low-diversity Antarctic soil nematode communities: Distribution and response to disturbance. Ecology, 78: 363-369.

Freckman D. W., and Virginia, R. A., 1998: Soil biodiversity and community structure in the McMurdo Dry Valleys, Antarctica. In Priscu, J. C. (ed.), Ecosystem Dynamics in a Polar Desert: The McMurdo Dry Valleys, Antarctica. Antarctic Research Series, Vol. 72. American Geophysical Union: Washington, D.C., 323-336.

Friedmann, E. I., Kappen, L., Meyer, M. A., and Nienow, J. A., 1993: Long-term productivity in the cryptoendolithic microbial community of the Ross Desert, Antarctica. Microbial Ecology, 25: 51-69.

Fritsen, C. P., Grue, A. M., and Priscu, J. C., 2000: Distribution of organic carbon and nitrogen in surface soils in the McMurdo Dry Valleys, Antarctica. Polar Biology, 23: 121-128.

Gardner, W. H., 1986: Water content. In Klute, A. (ed.), Methods of Soil Analysis: Part 1. Physical and Mineralogical Methods. 2nd ed. Madison, Wisc.: American Society of AgronomySoil Science Society of America, 493-544.

Gooseff, M. N., McKnight, D. M., Lyons, W. B., and Blum, A. E., 2002: Weathering reactions and hyporheic exchange controls on stream water chemistry in a glacial meltwater stream in the McMurdo Dry Valleys. Water Resources Research, 38: 1279, doi 10.1029/2001 WR000834.

Johnston, C. G., and Vestal, J. R., 1991: Photosynthetic carbon incorporation and turnover in Antarctic cryptoendolithic microbial communities: Are they the slowest-growing communities on Earth? Applied and Environmental Microbiology, 57: 2308-2311.

Keeney, D. R., and Nelson, D. W., 1982: Nitrogen-inorganic forms. In Page, A. L., Miller, R. H., and Keeney, D. R. (eds.), Methods of soil analysis: Part 2. Chemical and microbiological properties. 2nd ed. Agronomy Monograph No. 9. Madison, Wisc.: American Society of Agronomy-Soil Science Society of America, 643-698.

Kennedy, A. D., 1993: Water as a limiting factor in the Antarctic terrestrial environment: a biogeographical synthesis. Arctic and Alpine Research, 25: 308-315.

Keys, J. R., 1980: Air temperature, wind, precipitation and atmposheric humidity in the McMurdo Region. Geology Department, Victoria University, Wellington, New Zealand, Publication $17,57 \mathrm{pp}$.

Lancaster, N., 2002: Flux of aeolian sediment in the McMurdo Dry Valleys, Antarctica: a preliminary assessment. Arctic, Antarctic, and Alpine Research, 34: 318-323.

Lewis, K. J., Fountain, A. G., and Dana, G. L., 1998: Surface energy balance and meltwater production for a Dry Valley glacier, Taylor Valley, Antarctica. Annals of Glaciology, 27: 603-609.

Lyons, W. B., and Mayewski, P. A., 1993: The geochemical evolution of terrestrial waters in the Antarctic: The role of rockwater interactions. In Green, W. J. and Friedmann, E. I. (eds.), Physical and Biogeochemical Processes in Antarctic Lakes, Antarctic Research Series, vol. 59. Washington, D.C., American Geophysical Union: 135-143.
Matsuoka, N., 1995: Rock weathering processes and landform development in the Sor Rondane Mountains, Antarctica. Geomorphology, 12: 323-339.

McLean, E. O., 1982: Soil $\mathrm{pH}$ and lime requirement. In Page, A. L., Miller, R. H., and Keeney, D. R. (eds.), Methods of soil analysis: Part 2. Chemical and microbiological properties. 2nd ed. Agronomy Monograph No. 9. Madison, Wisc.: American Society of Agronomy-Soil Science Society of America, $199-224$.

Moorhead, D. L., Doran, P. T., Fountain, A. G., Lyons, W. B., McKnight, D. M., Priscu, J. C., Virginia, R. A., and Wall, D. H., 1999: Ecological legacies: impacts on ecosystems of the McMurdo Dry Valleys. Bioscience, 49: 1009-1019.

Nelson, D. W., and Sommers, L. E., 1982: Total carbon, organic carbon, and organic matter. In Page, A. L., Miller, R. H., and Keeney, D. R. (eds.), Methods of soil analysis: Part 2. Chemical and microbiological properties. 2nd ed. Agronomy Monograph No. 9. Madison, Wisc.: American Society of Agronomy-Soil Science Society of America, 539-579.

Overhoff, A., Freckman, D. W., and Virginia, R. A., 1993, Life cycle of the Microbivorous Antarctic Dry Valley Nematode Scottnema Lindsayae (Timm 1971). Polar Biology, 13: 151156.

Porazinska, D. L., Wall, D. H., and Virginia, R. A., 2002, Population age structure of nimatodes in the Antarctic Dry Valleys: Perspectives on time, space, and habitat suitability. Arctic, Antarctic, and Alpine Research, 34: 158-168.

Powers, L. E., Freckman, D. W., and Virginia, R. A., 1995: Spatial distribution of nematodes in polar desert soils of Antarctica. Polar Biology, 15: 325-334.

Powers, L. E., Ho, M., Freckman, D. W., and Virginia, R. A., 1998: Distribution, community structure and microhabitats of soil invertebrates along an elevational gradient in Taylor Valley, Antarctica. Arctic and Alpine Research, 30: 133-141.

Rhoades, J. D., 1982: Soluble salts. In Page, A. L., Miller, R. H., and Keeney, D. R. (eds.), Methods of soil analysis: Part 2. Chemical and microbiological properties. 2nd ed. Agronomy Monograph No. 9. Madison, Wisc.: American Society of Agronomy-Soil Science Society of America, 167-179.

Robertson, G. P., Wedin, D., Groffman, P. M., Blair, J. M., Holland, E. A., Nadelhoffer, K. J., and Harris, D., 1999: Soil carbon and nitrogen availability: Nitrogen mineralization, nitrification and soil respiration potentials. In Robertson, G. P., Coleman, D. C., Bledsoe, C. S. and Sollins, P. (eds.), Standard Soil Methods for Long Term Ecological Research. New York: Oxford University Press, 258-271.

Seastedt, T. R., and Vaccaro, L., 2001: Plant species richness, productivity, and nitrogen and phosphorus limitations across a snow-patch gradient in alpine tundra, Colorado, U.S.A. Arctic, Antarctic, and Alpine Research, 33: 100-106.

Treonis, A. M., Wall, D. H., and Virginia, R. A., 1999: Invertebrate biodiversity in Antarctic Dry Valley soils and sediments. Ecosystems, 2: 482-492.

Virginia, R. A., and Wall, D. H., 1999: How soils structure communities in the Antarctic Dry Valleys. Bioscience, 49: 973-983.

Walker, M. D., Walker, D. A., Welker, J. M., Arft, A. M., Bardsley, T., Brooks, P. D., Fahnestock, J. T., Jones, M. H., Losleben, M., Parsons, A. N., Seastedt, T. R., and Turner, P. L., 1999: Long-term experimental manipulation of winter snow regime and summer temperature in arctic and alpine tundra. Hydrological Processes, 13: 2315-2330.

Williams, M. W., Brooks, P. D., and Seastedt, T., 1998: Nitrogen and carbon soil dynamics in response to climate change in a high-elevation ecosystem in the Rocky Mountains, U.S.A. Arctic and Alpine Research, 30: 26-30.

Ms submitted December 2001 Revised ms submitted May 2002 